\title{
THE LEGAL PROCEDURE OF INTERDOMENIAL TRANSFER (FROM THE PUBLIC DOMAIN OF THE STATE TO THE PUBLIC DOMAIN OF THE TERRITORIAL-ADMINISTRATIVE UNITS, AND VICE VERSA) OF THE PUBLIC PROPERTY - LANDMARKS OF THE CASE-LAW OF THE CONSTITUTIONAL COURT ${ }^{1}$
}

DOI:10.47743/rdc-2020-2-0005

Irina Loredana GULIE, assistant-magistrate Constitutional Court of Romania

\section{Abstract}

This study presents landmarks of the case-law by which the Constitutional Court of Romania emphasized the constitutional way to transfer public property from the public domain of the State to the public domain of some territorialadministrative units, correlated with the transfer of the right of administration over the same buildings.

Keywords: public property; public domain of the State; public domain of territorialadministrative units; constitutional review; individual laws

\section{Introduction}

The right of public property is regulated in the Civil Code, Book III - About goods, Title VI - Public property, as well as by Government Emergency Ordinance No 57/2019 on the Administrative Code ${ }^{2}$. The latter regulatory act governs the specific rules regarding the exercise of the public property right of the State or of the territorialadministrative units, namely the composition of the public domain, the entities exercising the public property right of the State or of the territorial-administrative units, the transfer of property into the public domain, the administration, the concession, the rental and free use of public property.

The Constitutional Court has a rich and established case-law regarding the transfer of certain individually determined property from the public domain of the

${ }^{1}$ It contains Decisions of the Constitutional Court published in the Official Gazette of Romania, Part I, until 31 of December 2020.

2 Published in the Official Gazette of Romania, Part I, no. 555 of 5 July 2019. 
State into the public domain of the territorial-administrative units, a procedure currently regulated by the provisions of Article 292 of Government Emergency Ordinance No 57/2019 (which abrogated the correlative provisions contained in Article 9 of Law No 213/1998 on public property ${ }^{3}$ ).

$*$

Thus, from the analysis of the relevant case-law in this matter, the following rules can be structured, as a matter of principle, through which the content of Article 136 (2) and (3) of the Fundamental Law was defined, by reference to the provisions of the Civil Code, under the aspect of the regulatory act by which the goods are transferred from the public domain of the State to the public domain of the territorialadministrative units or vice versa.

\section{The general situation regarding the unconstitutionality of individual laws}

By the Decision of the Constitutional Court No 118 of 19 March 2018, paragraph 30, the Court reiterated its unified case-law (Decision No 600 of 9 November 20055, Decision No 970 of 31 October 20076, Decision No 494 of 21 November $2013^{7}$ and Decision No 574 of 16 October $2014^{8}$, paragraph 21), according to which the law, as a legal act of the Parliament, regulates general social relations, being, by its own essence and constitutional purpose, an act with general applicability. By definition, the law, as a legal act of power, is unilateral in nature, giving expression exclusively to the will of the legislator, whose content and form are determined by the need to regulate a particular field of social relations and its specificity. However, insofar as the scope of the regulation is determined in concrete terms, it is individual in nature, being designed not to be applied to an indeterminate number of specific cases, depending on whether they are covered by the rule, but, de plano, in a single case, unambiguously predetermined. Likewise, by Decision No 537 of 25 September 2019', paragraph 22, the Court held that, if the Parliament assumes its competence to legislate, under the conditions, scope and purpose pursued, the principle of separation and balance of State powers, enshrined in Article 1 (4) of the Constitution, is violated, which affects the law as a whole. The Court also held that the acceptance

${ }^{3}$ Published in the Official Gazette of Romania, Part I, no. 448 of 24 November 1998, subsequently amended and supplemented.

${ }_{4}^{4}$ Published in the Official Gazette of Romania, Part I, no. 367 of 27 April 2018.

${ }^{5}$ Published in the Official Gazette of Romania, Part I, no. 1.060 of 26 November 2005.

${ }^{6}$ Published in the Official Gazette of Romania, Part I, no. 796 of 22 November 2007.

7 Published in the Official Gazette of Romania, Part I, no. 819 of 21 December 2013.

${ }^{8}$ Published in the Official Gazette of Romania, Part I, no. 889 of 8 December 2014.

${ }^{9}$ Published in the Official Gazette of Romania, Part I, no. 907 of 8 November 2019. 


\section{The legal procedure of interdomenial transfer...}

of the idea that the Parliament can exercise its legislative power in a discretionary manner, at any time and under any conditions, by adopting laws in areas which belong exclusively to acts of an infralegal, administrative nature, would be equivalent to a deviation from the constitutional prerogatives of this authority, enshrined in Article 61 (1) of the Constitution, and to its transformation into an executive public authority.

Through the case-law cited above, the Court also held that the Parliament, assuming its competence to legislate, under the conditions, scope and purpose pursued, violated the principle of separation and balance of State powers, enshrined in Article 1 (4) of the Constitution, a flaw that affects the law as a whole. A law, adopted under the above conditions, infringes the constitutional principle on equality of rights, as it is enshrined in Article 16 (1) of the Basic Law, being discriminatory in nature and, as such, is totally unconstitutional. Likewise, Article 16 (2) of the Constitution is violated, indeed, insofar as a certain subject of law does not fall, by the effect of a legal provision adopted exclusively in its consideration and applicable only in respect of it, within the scope of a legal regulation constituting the common law in the matter, the legal provisions in question disregard the constitutional principle according to which "no one is above the law". The Court also noted that accepting the idea that Parliament may exercise its power to legislate in a discretionary manner, at any time and under any conditions, by adopting laws in areas which belong exclusively to acts of an infralegal, administrative nature, would be equivalent to a deviation from the constitutional prerogatives of this authority, enshrined in Article 61 (1) of the Constitution, and to its transformation into an executive public authority. However, such an interpretation does not comply with those ruled by the Constitutional Court in its case-law and, therefore, infringes the provisions of Article 147 (4) of the Constitution, which enshrine the erga omnes binding nature of the decisions of the Constitutional Court.

Regarding the regulatory nature of the law, the Constitutional Court held, by Decision No 600 of 9 November 2005, previously cited, that in the absence of an express prohibitive provision, as a matter of principle, the law shall be, as a rule, regulatory in nature, the primary nature of the regulations it contains being difficult to comply with their enforcement to a case or individual cases.

In this context, by Decision No 118 of 19 March 2018, previously cited, the Court found that the law, as a legal act of the Parliament, regulates general social relations, being, by its own essence and constitutional purpose, an act with general applicability. However, insofar as the scope of the regulation is determined in concrete terms, given the intuitu personae of the regulation, it is individual in nature, being designed not to be applied to an indeterminate number of specific cases, depending on whether they are covered by the rule, but, de plano, in a single case, unambiguously predetermined. 
3. Application of the general rule in the particular situation regarding the unconstitutionality of the regulation, by an individual law, of the transfer of public property from the public domain of the State to the public domain of the territorial-administrative units

By the Decision of the Constitutional Court No 406 of 15 June 2016 ${ }^{10}$, paragraph 28, it was held that, according to the last sentence of Article 136 (3) of the Fundamental Law, read in conjunction with the first sentence of Article 860 (3) of the Civil Code, in the case of property forming the exclusive object of the public property of the State or of territorial-administrative units by virtue of an organic law, the transfer from the public domain of the State into the public domain of the territorialadministrative units or vice versa shall only operate through an amendment to the organic law, (namely by the adoption of an organic law amending the organic law by which the property was declared to be the exclusive object of the public property $\mathrm{A} / \mathrm{N}$ ). At the same time, according to Article 136 (2) of the Constitution, read in conjunction with the second sentence of Article 860 (3) of the Civil Code, in all other cases, namely when the property belongs, according to its intended purpose, either to the public domain of the State or to the public domain of the territorial-administrative units, the transfer from the public domain of the State to that of territorialadministrative units or vice versa shall be carried out in accordance with the law, respectively Article 292 (1) of Government Emergency Ordinance No 57/2019 on the Administrative Code, namely at the request of the County Council, the General Council of the Bucharest Municipality or the Local Council, as the case may be, or by Government decision or, symmetrically, at the request of the Government, by decision of the County Council, the General Council of the Bucharest Municipality or the Local Council (in regard to this, see also the Decision of the Constitutional Court No 1 of 10 January 2014 11 , paragraphs 176-178). Therefore, the legislative instruments used for carrying out the transfer of property from the public domain of State into the public domain of the territorial-administrative units, are either the organic laws amending the organic law by which the property was declared to be the exclusive object of the public property of the State, or the Government decisions, when the property does not constitute the exclusive object of the public property of the State.

As concerns the property forming the exclusive object of the public property of the State or of the territorial-administrative units, being declared as such by an organic law, the Court held, as a matter of principle, by Decision no. 406 of 15 June 2016, cited above, paragraph 31, that, in the particular situation of the property forming the exclusive object of the public property of the State or of the territorialadministrative units, the only possibility of transfer of such property from the public

\footnotetext{
${ }^{10}$ Published in the Official Gazette of Romania, Part I, no. 533 of 15 July 2006.

11 Published in the Official Gazette of Romania, Part I, no. 123 of 19 February 2014.
}

\section{CONSTITUTIONAL LAW REVIEW}


domain of the State into the public domain of the territorial-administrative units is the ut singuli transfer (by the organic law amending the organic law whereby the property has been declared the exclusive object of public property). Therefore, in such a situation, the recitals held in the case-law of the Court, according to which the laws thus adopted are unconstitutional, as they would have an individual nature, are not applicable in the present case. However, this particular situation concerns only the property forming the exclusive object of the public property of the State or of the territorial-administrative units, based on the provisions of Article 136 (3), final sentence, of the Constitution, in conjunction with the provisions of the first sentence of Article 860 (3) of the Civil Code.

As concerns the property not forming the exclusive object of the public property which could belong, according to the intended purpose, either to the public domain of the State, or to the public domain of the territorial-administrative units, by the same decision, paragraph 28, the Court held that the transfer shall be carried out under the law, namely for that property which is transferred from the public property of the State into that of the territorial-administrative units, being carried out under the conditions of Article 292 (1) of Government Emergency Ordinance no. 57/2019, by Government decision.

Likewise, by the Decision of the Constitutional Court No 384 of 29 May 201912, paragraphs 43-45, the Court, finding that the interdomenial transfers of public property, regulated by Articles 292 and 293 of the Administrative Code, are carried out through administrative acts - Government decisions, at the request of Local, County or General Councils of Bucharest, as well as at the request of the Government, by the decisions of the said councils, held that this method of regulation, by the special law, is based on the provisions of Article 102 (1), final sentence, and of Article 120 (1) of the Constitution. In order to give efficiency to the constitutional provisions, the legislator regulated a separate legal regime of the property forming the object of the public property of the State and of the territorial-administrative units. In this regard, the interdomenial transfer shall be established according to their needs, subsequent to the transfer of the public property right, constituting the right of administration regarding the property. The transfer request, mandatory according to the impugned regulatory act, shall be made by the Government or the mentioned councils and must have a ground/reason, and the act by which the transfer is carried out, decision of the Government or councils, can be challenged before the administrative courts of law.

Likewise, by the Decision of the Constitutional Court No 1 of 10 January 2014, previously cited, paragraph 188, it was held that the right of administration is constituted, as the case may be, by the decision of the Government, of the County Council, of the General Council of Bucharest or of the Local Council, by administrative

12 Published in the Official Gazette of Romania, Part I, no. 499 of 20 June 2019.

CONSTITUTIONAL NEWS 
acts of an individual nature, of entrusting the public property to the autonomous administrations or, as the case may be, to the central or local public administration authorities and other national, county or local public institutions, the constituting authorities having also the right to control the way in which the administration right shall be exercised by its holder. At the same time, by the aforementioned decision, paragraph 190, the Court also noted that the transfer from public property of the State into public property of territorial-administrative units and to the administration of County Councils, namely of the General Council of Bucharest, cannot amount to the legal operation of establishing the real right of administration, given the fact that the territorial-administrative units cannot have the quality of subjects of the right of administration, since they are even the holders of the right of public property. Moreover, by transferring the right of public property to the territorial-administrative unit, the State cannot, at the same time, constitute the right of administration in favour of the local public administration authorities, as it is no longer the holder of the corresponding public property right which it has just transferred it.

Being notified to rule upon the constitutionality of certain laws governing the transfer of ownership over individualized immovable property, usually in the annexes to these regulatory acts, from the public domain of the State to the public domain of some territorial-administrative units, simultaneously with the transfer of the right of administration, the Constitutional Court, applying the principles retained, as a matter of principle, in the case-law cited above, found that these regulatory acts are unconstitutional, as a whole.

Thus, by the Decision of Constitutional Court No 636 of 23 September 2020 ${ }^{13}$, it was upheld the objection of unconstitutionality of the Law on the transfer of immovable property from the public domain of the State and from the administration of the National Administration "Romanian Waters" - Dobrogea Water Basin Administration - Shore in the public domain of Ceatalchioi and Crisan Communes, Tulcea County and it was found the infringement of Article 1 (4) and (5), Article 61 (1), Article 102 (1) final sentence, Article 120 (1) and Article 147 (4) of the Constitution, determined by the fact that by the law subject to constitutional review the legislative authority regulated in a field related to administration and executive authority, namely regarding the transfer of individual immovable property, not forming the exclusive object of public property.

The Court held that the impugned law shall operate an interdomenial transfer of immovable property - determined individually in the annex that is an integral part of the law - which concerns the water supply network of Ceatalchioi, Pătlăgeanca and Caraorman in Tulcea County, property that is currently provided at point 4 of Annex No 4 - The list comprising certain property belonging to the public domain of the commune, of the city or of the municipality, to Government Emergency Ordinance

13 Published in the Official Gazette of Romania, Part I, no. 934 of 12 October 2020.

\section{CONSTITUTIONAL LAW REVIEW}


no. 57/2019 on the Administrative Code, these lists being exemplary in nature. The Court, in accordance with its previous case-law, (Decision no. 538 of 25 September 201914, paragraph 24), held that the nomination in the annex to the Administrative Code does not have the meaning of its declaration as property forming the exclusive object of public property. The enumeration in the annex has an exemplary nature, and through this an attempt was tried in order to delimit, as a matter of principle, the public domain of the State, the county public domain and the local public domain of communes, cities and municipalities. Under these circumstances, given that the property subject to the transfer regulated by the impugned law does not form an exclusive object of public property, in the absence of an express provision of the organic law, the Court held that it should have been transferred from the public property of the State into the territorialadministrative unit by Government decision, at the request of the Local Council of Ceatalchioi Commune and of the Local Council of Crişan Commune, according to Article 292 (1) of the Administrative Code, in force at the time of the adoption of the impugned law. Consequently, the Court found that the law did not comply with the legal conditions in force, subject to the regulated matter, so that it was adopted in violation of Article 1 (5) of the Constitution, regarding the observance of the Constitution, its supremacy and the laws.

At the same time, from the perspective of the established case-law of the Constitutional Court in the matter and of the provisions of Article 147 (4) of the Constitution, it was noted that the decisions of the Constitutional Court related to the prohibition of the regulation by law regarding a specific case were not observed. It was also held the violation of the principle of local autonomy and the impossibility of establishing the right of administration, simultaneously with that of property, as well as the exceptional situation in which the transfer of property from the exclusive public property of the State and the territorial-administrative units may be carried out by organic law, taking into account the recitals noted, as a matter of principle, in Decision No 1 of 10 January 2014 and Decision No 406 of 15 June 2016, cited above.

By the Decision of the Constitutional Court No 683 of 30 September $2020^{15}$, it was upheld the objection of unconstitutionality of the Law on the transfer of a land under the administration of the Ministry of Transport, Infrastructure and Communications and in the concession of the National Railway Company C.F.R. - S.A., from the public domain of the State into the public domain of Bucharest and it was found that the transfer of the property in question by law, an act subject to the legislative authority, into a domain subject to administration and executive authority infringes Article 1 (4) and (5), Article 61 (1), Article 102 (1), final sentence, and Article 120 (1), Article 136 (2) and Article 147 (4) of the Constitution.

The Court held that the property in question is an immovable property-land, related to the Bucharest-Progresul-Bucharest-Cotroceni railway line, and, in a generic

\footnotetext{
14 Published in the Official Gazette of Romania, Part I, no. 908 of 11 November 2019.

15 Published in the Official Gazette of Romania, Part I, no. 1184 of 7 December 2020.
}

CONSTITUTIONAL NEWS 
way, it is part of a category of property mentioned in point 10 of Annex No 2 to the Administrative Code, entitled List of certain property belonging to the public domain of the State, having the following content: "10. railway infrastructure, including tunnels and works of art", and according to Article 11 (1) of Government Emergency Ordinance No 12/1998 regarding the transport on Romanian railways and the reorganization of the National Society of Romanian Railways, republished in the Official Gazette of Romania, Part I, no. 834 of 9 September 2004, "the public railway infrastructure consists of: a) the railway lines, the related land on which they are built, as well as the lands located on both sides of the railway axis, which constitute the safety area of the railway infrastructure; (...)".

Therefore, the Court noted that, being generically nominated in the category of public property - the railway infrastructure, which, according to the special law, includes the land related to the railway lines, the property covered by the impugned law is not an exclusive public property. Under these conditions, it should have been transferred from the public property of the State into that of the territorialadministrative unit by Government decision, at the request of the General Council of the Municipality of Bucharest, according to Article 292 (1) of the Administrative Code.

Likewise, the Court noted that, in the absence of the agreement of the territorialadministrative unit, in this case the General Council of Bucharest Municipality, regarding the transfer of assets into the patrimony of the territorial-administrative unit, the constitutional principle of local autonomy, regulated by Article 120 (1) of the Constitution, is also violated (see, in this regard, the Decision of the Constitutional Court No 537 of 25 September 2019, previously cited, paragraph 25). At the same time, the non-observance of the specific legal procedure of interdomenial transfer amounts to the violation of the provisions of Article 136 (2) of the Constitution, according to which "public property is guaranteed and protected by law, and belongs to the State or to territorial-administrative units", as well as to the provisions of Article 147 (4) of the Constitution, because, as shown, the decisions of the Constitutional Court on the prohibition of regulation by law regarding a specific case are not observed.

Identical recitals also substantiated the Decision of the Constitutional Court No 684 of 30 September $2020^{16}$, by which it was found the unconstitutionality of the Law on the transfer of certain lands from the public domain of the State and the administration of the Ministry of Environment, Waters and Forests - National Directorate of Forests - Romsilva into the public domain of Slatina and the administration of the Local Council of Slatina.

At the same time, by the Decision of the Constitutional Court No 901 of 16 December $2020^{17}$, it was upheld the objection of unconstitutionality of the Law on the transfer of property from the public domain of the State and from the administration of

\footnotetext{
${ }^{16}$ Published in the Official Gazette of Romania, Part I, no. 1185 of 7 December 2020.

17 Published in the Official Gazette of Romania, Part I, no. 126 of 5 February 2021.
}

\section{CONSTITUTIONAL LAW REVIEW}


the State Domains Agency, into the public domain of Odobeşti, Vrancea County and it was found that the interdomenial transfer regulated by the impugned law, by law, an act subject to the legislative authority, into a domain subject to the executive authority, infringes Article 1 (4) and (5), Article 52, Article 61 (1), Article 102 (1), final sentence, Article 120 (1), Article 136 (2) and (4), as well as Article 147 (4) of the Constitution.

The Court held that the property covered by the impugned law is an immovable property - land, located in the public domain of the State and in the administration of the State Domains Agency, owned by Odobeşti Technological High School. In connection with this category of property, the Court noted that it is stipulated, by way of example, in Annex No 4 point 5 of Government Emergency Ordinance No 57/2019 on the Administrative Code, entitled List of certain property belonging to the public domain of the commune, town or municipality, having the following content: "5. lands and buildings where the Local Council and the mayor's office operate, as well as local public institutions, such as theatres, libraries, museums, hospitals, polyclinics and others similar". At the same time, in connection with the legal regime of the property concerned, the Court also noted that the holder of the concession right is a local public institution, which is mentioned, at point 57, in the list of technological high schools with a predominantly agricultural profile provided in the annex to the Order of the Minister of National Education and of the Minister of Agriculture and Rural Development No 4.215/296/2019 for the approval of the list of technological high schools with a predominantly agricultural profile, published in the Official Gazette of Romania, Part I, no. 477 of 12 June 2019. Likewise, the immovable property covered by the impugned law is identified in Annex No 3 to Government Decision no. 1.705/2006 for the approval of the centralized inventory of property belonging to the public domain of the State, published in the Official Gazette of Romania, Part I, no. 1.020 and 1.020 bis of 21 December 2006, as subsequently amended and supplemented.

Under these circumstances, given that the property subject to the transfer regulated by the impugned law does not form an exclusive object of public property, in the absence of an express provision of the organic law, it should have been transferred from the public property of the State to that of the territorialadministrative unit, by Government decision, at the request of the Local Council of Odobeşti, Vrancea County, according to Article 292 (1) of the Administrative Code. Thus, the impugned law did not comply with the legal conditions in force, subject to the regulated matter, so it was adopted in violation of Article 1 (5) of the Constitution, regarding the observance of the Constitution, its supremacy and the laws (in this regard, see also Decision no. 636 of 23 September 2020, cited above, paragraph 42).

The Court noted that the property subject to the impugned law was transferred opelegis from the public domain of the State into the public domain of Odobeşti City, Vrancea County, so that the manner of establishing the right of administration over public property, subject to interdomenial transfer, under the conditions of the impugned law, is incompatible with the concept and the legal nature of the real right

CONSTITUTIONAL NEWS 
of administration, corresponding to the right of public property, and, consequently, it infringes the provisions of Article 136 (4) of the Fundamental Law, which constitutionally enshrines the ways of exercising the right of public property. Moreover, in the absence of the agreement of the territorial-administrative unit, in this case the Local Council of Odobeşti, Vrancea County, regarding the transfer of the property into the patrimony of the territorial-administrative unit, the constitutional principle of local autonomy is also violated, regulated by Article 120 (1) of the Constitution (see, in this regard, Decision No 537 of 25 September 2019, cited above, paragraph 25).

At the same time, in accordance with its relevant case-law (Decision No 384 of 29 May 2019, cited above, paragraphs 54 and 55), the Court also held that the regulation of the transfer from the public property of the State into the public property of the territorial-administrative units of the property not forming an exclusive object of public property, by Government decision, allows the exercise of legality control over such property by the administrative courts of law, thus giving efficiency to the provisions of Article 52 of the Fundamental Law. However, by regulating the transfer by law, and not by Government decision, of the property not forming the exclusive object of public property, the possibility of the injured person by a public authority through an administrative act to challenge before a court is circumvented. Thus, the provisions of Article 52 of the Fundamental Law become inapplicable in a domain exclusively subject to the transfer of the right of public property over the goods, by the Government, which exercises the general management of the public administration. Therefore, the Court also held the infringement of the provisions of Article 52 of the Constitution.

\section{$* *$ \\ 4. Conclusions}

By the aforementioned case-law, the Constitutional Court of Romania emphasized the constitutional way to transfer public property from the public domain of the State to the public domain of some territorial-administrative units, correlated with the transfer of the right of administration over the same buildings.

In essence, these interdomenial transfers cannot interfere with ope legis, but with the observance of some rules, the incidence of which is determined by the exclusive or non-exclusive nature of the property belonging to the transfer to the public domain of the State or of the territorial-administrative unit. Thus, in case the property forming the exclusive object of the public property of the State or of the territorial-administrative unit, under an organic law, the transfer from the public domain of the State to the public domain of the territorial-administrative units or vice versa operates only by a modification of the organic law, namely by adopting an 
The legal procedure of interdomenial transfer...

organic law amending the organic law by which the property was declared the exclusive object of public property. In other cases, namely when the property belongs, according to its intended purpose, either to the public domain of the State or to the public domain of the territorial-administrative units, the transfer from the public domain of the State to that of territorial-administrative units or vice versa shall be carried out in accordance with Article 292 (1) of the Government Emergency Ordinance No 57/2019 on the Administrative Code, namely at the request of the County Council, the General Council of the Bucharest Municipality or the Local Council, as the case may be, or by Government decision or, symmetrically, at the request of the Government, by decision of the County Council, the General Council of the Bucharest Municipality or the Local Council. 